\title{
ANALISA PENGARUH PENGGUNAAN ALAT PELINDUNG DIRI (APD) TERHADAP ALLOWANCE PROSES KERJA PEMOTONGAN KAYU (STUDI KASUS : PT. PAL INDONESIA)
}

\author{
Asri Sugarda, Indri Santiasih *), Anda Iviana Juniani \\ Politeknik Perkapalan Negeri Surabaya
}

\begin{abstract}
Abstrak
Adanya peralatan kerja yang dapat menimbulkan potensi bahaya dan sudah tidak memungkinkan lagi untuk dilakukan pengendalian secara engineering control membuat para pekerja yang mengoperasikan peralatan kerja tersebut dituntut untuk melakukan pengendalian dengan memaksimalkan penggunaan Alat Pelindung Diri (APD), seperti kondisi yang tejadi di PT. PAL Indonesia (PERSERO) tepatnya pada Divisi Kapal Niaga terutama pada area Bengkel Kayu. Namun, seringkali penggunaan APD diabaikan oleh para pekerja. Hal ini dikarenakan ketidaknyamanan kesulitan bekerja yang dirasakan oleh para pekerja saat mengenakan APD. Hal inilah yang memicu untuk dilakukannya penelitian guna mengetahui Waktu Normal (WN), Waktu Standar (WS), Output Standart (OS) dan pengaruh penggunaan APD terhadap allowance dari pelaksanaan suatu proses kerja. Penelitian ini dilakukan dengan menggunakan metode work sampling. Nilai allowance dari hasil pengamatan dengan metode work sampling diuji dengan menggunakan software Minitab dan one-way ANOVA. Hasil dari uji one-way ANOVA, didapatkan nilai P sebesar 0,001 . Jika hipotesa $\alpha=0,05$ maka nilai P lebih kecil dari nilai $\alpha$, sehingga dapat diketahui bahwa penggunaan APD mempunyai pengaruh terhadap allowance.
\end{abstract}

Kata kunci : alat pelindung diri (APD); allowance; work sampling; minitab; one-way ANOVA

\begin{abstract}
The existence of work equipment which may pose a potential danger and is no longer possible to do the engineering controls to control the workers who operate the work equipment is required to exercise any control by maximizing the use of Personal Protective Equipment (PPE), such a condition occurs in the PT. PAL Indonesia (Persero) precisely at the Division of Commercial Ship Repair Wood especially in the area. However, the use of PPE is often overlooked by workers. This is due to the discomfort felt by working hard workers when wearing PPE. This is what triggers to do research to determine the Normal Time (WN), Standard Time (WS), Output Standard (OS) and the effect of the use of PPE against the allowance of the implementation of a work process. This research work carried out by using the method of sampling. Allowance value of observation work sampling method was tested using Minitab software and one-way ANOVA. The results of one-way ANOVA test, showed a P value of 0.001. If the hypothesis $\alpha$ $=0.05$ then the $P$ value is smaller than the value of $\alpha$, so it can be seen that the use of PPE have an influence on allowance.
\end{abstract}

Keywords: personal protective equipment; allowances; work sampling; minitab;one-way ANOVA

\section{Pendahuluan}

Menurut Occupational Safety and Health Administration (OSHA) [1], APD didefinisikan sebagai alat yang digunakan untuk melindungi pekerja dari luka atau penyakit yang diakibatkan oleh adanya kontak dengan bahaya (hazard) di tempat kerja, baik yang bersifat kimia, biologis, radiasi, elektrik, mekanik dan lainnya. Dalam UndangUndang Keselamatan dan Kesehatan Kerja No. 1

\footnotetext{
${ }^{*}$ Penulis Korespondensi. email: indri.santiasih@gmail.com
}

Tahun 1970 [2] tertulis tentang keharusan yang dilakukan oleh perusahaan untuk melakukan usaha pencegahan terjadinya kecelakaan yang diantaranya dengan menyediakan APD. Pemakaian APD meruakan alternatif terkhir dari upaya pencegahan kecelakaan kerja. Dalam hirarki hazard control atau pengendalian bahaya, penggunaan alat pelindung diri merupakan metode pengendali bahaya paling akhir. Artinya, sebelum memutuskan untuk menggunakan APD, metode-metode lain harus dilalui terlebih dahulu dengan melakukan upaya optimal agar bahaya atau hazard bisa dihilangkan atau paling tidak diminimalisir. 
Pada Divisi Kapal Niaga utamanya di bagian Bengkel Kayu PT. PAL Indonesia (PERSERO) terdapat peralatan yang menimbulkan potensi bahaya dan sudah tidak memungkinkan lagi untuk dilakukan pengendalian secara engineering control maupun administrative control sehingga pengguaan APD menjadi cara terakhir yang harus di aplikasikan untuk mencegah atau meminimalisir bahaya yang akan terjadi. Namun dengan diketahuinya potensi bahaya yang ada dan pentingnya penggunaan APD selama proses kerja berlangsung, masih saja terdapat beberapa pekerja yang mengabaikan dan tidak mau menggunakan APD yang telah disediakan. Sebab mereka merasa tidak nyaman dan merasa kesulitan saat melakukan pekerjaan dengan mengenakan APD yang ada. Dengan adanya persoalan tersebut maka peneliti bermaksud untuk pelakukan penelitian mengenai pengaruh penggunaan APD terhadap allowance (waktu yang dibutuhkan pekerja untuk beristirahat) yang nantinya mengacu terhadap produktivitas kerja para pekerja.

\section{Tinjauan Pustaka \\ Alat Pelindung Diri (APD)}

APD merupakan suatu alat yang diperlukan untuk melindungi seseorang dari potensi bahaya fisik maupun kesehatan yang tidak dapat dihilangkan melalui pengendalian teknik/engineering control maupun pengendalian administratif/administrative control. Pengendalian teknik adalah menghilangkan potensi bahaya yang berhubungan dengan mesin atau melalui proses desain. Sedangkan pengendalian administratif merupakan teknik manajemen, seperti mengatur waktu kerja pada pekerjaan yang dapat mengakibatkan para pekerja dapat terpapar melebihi batas aman, sehingga pekerja hanya akan terpapar bahaya dengan ketentuan diwawah nilai ambang batas atau dapat dikatakan aman. Walaupun untuk meyakinkan pekerja untuk memakai APD sangat sulit namun kemungkinan kecelakaan adalah rendah tetapi hal tersebut adalah konsekuensi yang berat. [3]

1. Dalam pemilihan APD harus memperhatikan hal hal seperti berikut:

- Harus sesuai dengan tipe/jenis pekerjaan

- Mampu memberikan perlindungan bagi pengguna

- Tidak menimbulkan bahaya keselamatan dan keseatan tambahan

- Mudah untuk digunakan dan bentuknya harus menarik

- Member kenyamanan bagi pengguna

- Harus dapat dipakai secara flesibel

- Harus memenuhi ketentuan yang ada

- Tidak mudah rusak

- Harganya murah dan suku cadangnya tersedia

- Tidak mengganggu gerak bagi pengguna

2. Macam-macam APD

- Alat pelindung kepala/safety helmet

- Alat pelindung mata/goggles/safety glasses

- Alat pelindung muka/face shield/face mask
- Alat pelindung telinga/earmuffs/earplug

- Alat pelindung pernapasan/respirator

- Alat pelindung tangan/gloves

- Alat pelindung kaki/safety shoes

- Alat pelindung badan/apron

- Alat pelindung pada ketinggian/safety harness

\section{Work sampling}

Sampling atau dalam bahasa asing disebut dengan work sampling, ratio delay study atau random observation method adalah suatu teknik untuk mengadakan sejumlah besar pengamatan terhadap aktifitas kerja dari mesin, proses atau kerja operator. Pengukuran kerja dengan menggunakan metode work sampling ini seperti halnya pengukuran kerja dengan jam henti (stop watch time study) diklasifiasikn sebagai pengukuran kerja secara langsung, karena pelaksanaan kegiatan pengukuran harus secara langsung ditempat kerja yang diteliti.

1. Tujuan work sampling

- Mengukur "Ratio Delay" dari sejumlah mesin, karyawan/operator, atau fasilitas kerja lainnya. Sebagai contoh ialah untuk menentukan prosentase dari jam atau hari dimana mesin atau orang benar-benar terlibat dalam aktivitas kerja, dan prosentase dimana sama sekali tidak ada aktivitas kerja yang dilakukan (menganggur atau idle).

- Menetapkan "Perormance Level" dari seseorang selama waktu kerjanya berdasarkan waktuwaktu dimana orang ini bekerja atau tidak bekerja terutama sekali untuk pekerjaanpekerjaan manual.

- Menentukan waktu baku untuk suatu proses/operasi kerja seperti halnya yang bisa dilaksanakan oleh pengukuran kerja lainnya.

2. Keutungan dan kerugian work sampling

- Keuntungan work sampling

a. Lebih efektif, karena dengan cepat \& mudah dalam menghasilkan data.

b. Lebih efisien, karena informasi yang dikehendaki akan didapatkan dalam waktu relatif lebih singkat.

c. Biayanya tidak terlalu besar

d. Cara pengukuran lebih sederhana \& praktis

e. Tidak perlu meneliti semua operator, cukup dengan sejumlah sample

f. Output yang dihasilkan cukup baik (terutama jika digunakan derajat ketelitian rendah \& tingkat kepercayaan tinggi).

- Kerugian work sampling

a. Tingkat ketelitiannya kurang baik

b. Kurang cocok untuk mengukur kerja yang repetitive

c. Kurang baik untuk mengukur kerja yang berlangsung singkat, untuk setiap siklus kerjanya.

d. Karakteristik operator yang terpilih berbeda dengan kondisi sebenarnya

e. Penetapan elemen kerja tidak bisa mendetail. 
3. Siklus pelaksanaan work sampling, siklus pelaksanaan work sampling kerja adalah sebagai berikut:

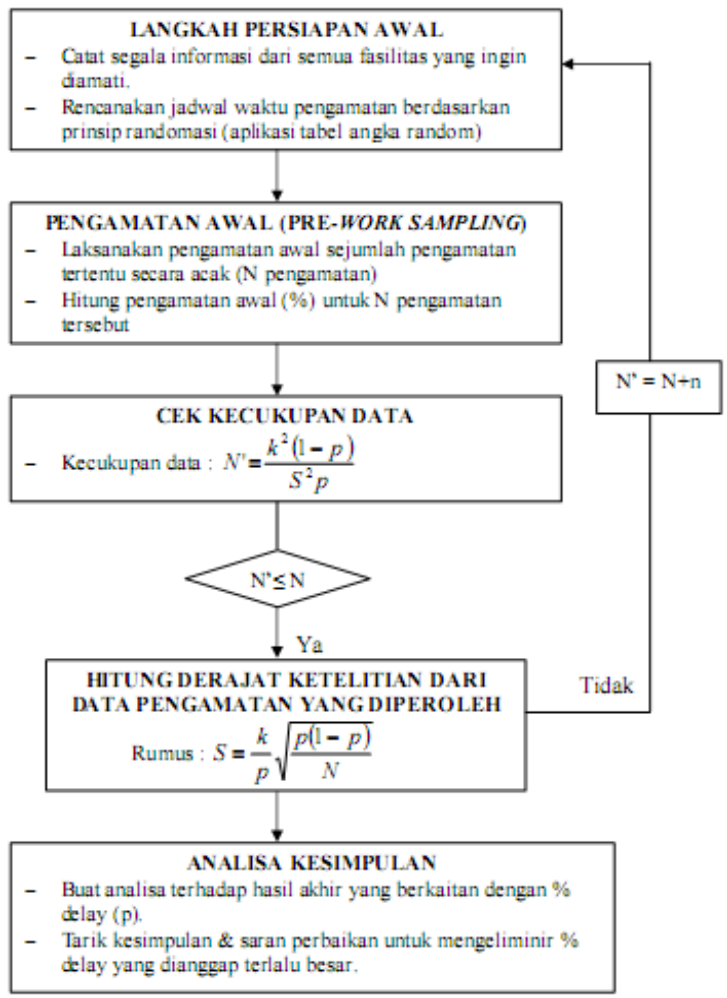

Gambar 1. Langkah-langkah Sistematis dari Aktivitas Work Sampling

4. Penggunaan tabel angka acak

Untuk melakukan pengamatan dalam work sampling maka disini masing-masing kejadian yang diamati selama aktivitas kerja berlangsung harus memiliki kesempatan yang sama untuk diamati. Dengan kata lain pengamatan haruslah dilaksanakan secara acak (random). Untuk maksud ini maka penggunaan tabel angka acak (random number tables) barang kali merupakan metode yang terbaik guna menjamin bahwa sample pengamatan yang diambil benar-benar dipilih secara acak. Tabel angka acak ini akan bisa ditemui atau dilihat dalam setiap lampiran dari buku-buku statistik.

5. Derajat ketelitian dan tingkat kepercayaan Banyaknya pengamatan yang harus dilakukan dalam work sampling akan dipengaruhi oleh tingkat ketelitian/degree of accuracy dan tingkat kepercayaan/level of convidence. Dengan asumsi bahwa terjadinya kejadian seorang operator akan bekerja/menganggur mengikuti pola distribusi normal maka untuk mendapatkan jumlah sampel pengamatan harus dicari dengan menggunakan rumus berikut:

$$
s-\frac{\hbar}{p} \sqrt{\frac{p(1-p)}{N}}-(2.1)
$$

J@TI Undip, Vol IX, No 3, September 2014
Dimana:

$S=$ tingkat ketelitian yang dikehendaki dan dinyatakan dalam desimal

$p=$ prosentase terjadinya kejadian yang diamati dan juga dinyatakan dalam bentuk desimal

$N=$ jumlah pengamatan yang harus dilakukan untuk sampling kerja/work sampling

$k=$ harga indeks yang besarnya tergantung dari tingkat kepercayaan yang diambil

*untuk tingkat kepercayaan $68 \%$ harga $\mathrm{k}$ adalah 1 untuk tingkat kepercayaan $95 \%$ harga k adalah 2 untuk tingkat kepercayaan $99 \%$ harga k adalah 3

\section{Allowance}

Allowance adalah lama waktu yang terjadi saat sebuah "interupsi" berlangsung dalam sebuah aktivitas rutin operasional yang sulit untuk diukur dengan menggunakan metode stop watch time study. Macam-macam allowance, diklasifikasikan menjadi 3 macan yaitu:

- Personal Allowance, merupakan waktu yang dipertimbangkan untuk pekerja untuk mengurus kebutuhan individu, seperti: pergi ke kamar kecil dan minum. (Department of Defense 5010.15-1-M, 1977)

- Fatigue Allowance, merupakan waktu yang dipertimbangkan untuk menyembuhkan diri dari kelelahan.

- Delay Allowance, keterlambatan atau delay bisa disebabkan oleh faktor-faktor yang sulit untuk dihindarkan (unavoidable delay), tetapi bisa juga disebabkan oleh beberapa faktor yang sebenarnya masih bisa untuk dihindari. Keterlambatan yang terlalu besar/lama tidak akan dipertimbangkan sebagai dasar untuk Menetapkan waktu baku. Untuk avoidable delay disini terjadi dari saat ke saat yang umumnya disebabkan oleh mesin, operator, ataupun hal-hal lain yang diluar kontrol.

\section{Waktu Normal, Waktu standar dan Output Standar}

1. Waktu Normal, dapat diartikan sebagai waktu yang dibutuhkan oleh seorang operator dalam menyelesaikan pekerjaannya pada tembo/kecepatan yang normal. Namun pada kenyataannya operator akan sering menghentikan kerja untuk keperluan seperti personal needs, istirahat melepas lelah dan alasan lain diluar kontrolnya.

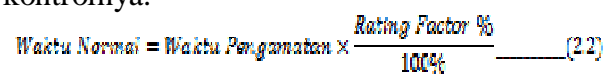

Rating Factor ini didasarkan pada satu faktor tunggal yaitu operator speed, space atau tempo. Rating Factor ini umumnya dinyatakan dalam prosentase atau angka desimal, dimana kerja normal akan sama dengan $100 \%$ atau 1,00 . Rating Factor diaplikasikan untuk menormalkan waktu kerja yang diperoleh dari pengukuran kerja akibat tempo atau kecepatan kerja operator yang berubah-ubah.[4] 
2. Waktu Standar. Personal Allowance umumnya diaplikasikan sebagai prosentase tertentu dari waktu normal dan bisa berpengaruh pada handling time maupun machine time. Untuk mempermudah perhitungan, fatigue allowance juga dinyatakan sama (prosentase dari waktu normal) dan begitu pula dengan delay. Sedangkan untuk mempermudah waktu standar guna penyelesaian suatu operasi kerja maka waktu normal harus ditambah dengan waktu allowance (yang merupakan prosentase dari waktu normal). Disamping itu ada kecenderungan untuk mempertimbangkan waktu allowance sebagai waktu yang diberikan/dilonggarkan untuk berbagai macam hal per hari kerja.

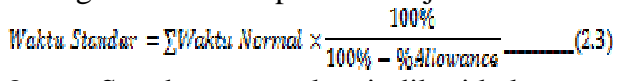

3. Output Standar, merupakan indikasi keluaran yang mampu dihasilkan oleh seorang pekerja. Hasil keluaran yang dihasilkan oleh seorang pekerja merupakan suatu ketetapan berdasarkan tingkat kemampuan rata-rata pekerja untuk menyelesaikan suatu pekerjaan dan didalamnya sudah meliputi kelonggaran-kelonggaran waktu yang diberikan sesuai dengan situasi dan kondisi pekerjaan itu sendiri.

Output Standar $=\frac{1}{\text { Walctu Standart }}$

\section{Metodologi Penelitian}

Tahapan-tahapan yang dilakukan dalam Analisa Pengaruh Penggunaan Alat Pelindung Diri (APD) Terhadap Allowance adalah dengan melakukan Prework Sampling dan Work Sampling guna melakukan uji kecukupan data dengan N' yang digunakan dibatasi sebesar sovo $<$ data $\leq 7000$. Kemudian melakukan perhitungan Allowance, Waktu Normal, Waktu Standart, dan Output Standar. Setelah seluruh data dikumpulkan dan dihitung tahapan selanjutnya adalah melakukan proses analisa dengan menguji data-data yang ada dengan one-way ANOVA guna mengetahui ada atau tidaknya pengaruh APD terhadap Allowance.

\section{Pengolahan Data \& Analisis}

Dalam pengambilan data baik pre-work sampling maupun work sampling dilakukan dengan beberapa ketentuan sebagai berikut:

a. Pengambilan data dilakukan pada Bengkel Kayu, Divisi Kapal Niaga PT. PAL Indonesia (Persero), Surabaya.

b. Waktu pengamatan dilakukan mulai pukul 08.00 WIB sampai dengan selesai.

c. Obyek yang akan diamati adalah pekerjaan pembelahan kayu dengan menggunakan mesin straight line saw, yang berfungsi untuk membelah kayu dengan ketebalan kayu $1-5 \mathrm{~cm}$.

d. Jumlah operator yang diamati sebanyak 3 orang dengan 3 perlakuan yaitu:

J@TI Undip, Vol IX, No 3, September 2014
- Pekerja pertama mengenakan APD sepatu safety, cattle pack, masker, kacamata dan helmet.

- Pekerja kedua mengenakan APD sepatu safety, cattle pack dan, kacamata.

- Pekerja ketiga mengenakan APD sepatu safety dan cattle pack

\section{Pengumpulan data pre-work sampling}

Dalam pekerjaan pembelahan kayu terdiri dari 4 elemen kerja yaitu mengangkat atau meletakkan material ke conveyor, memposisikan material dan memasukkan material ke dalam mesin, Proses pembelahan material beserta pengecekan material dan Penataan material.

Hasil Pre-work Sampling dapat dilihat pada Tabel 1 berikut:

Tabel 1. Hasi Pre-work Sampling

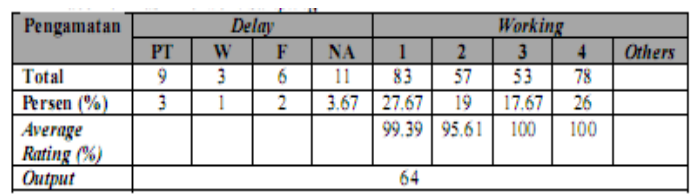

* Keterangan:

a. $\mathrm{PT}=$ Personal Time (ke kamar mandi, minum, merokok, ngobrol, bersin-bersin, mengusap mata).

b. $\mathrm{W}=$ Waiting (menunggu selesainya aktivitas dari pekerja lain, menunggu row material, perbaikan mesin akibat kerusakan ringan.

c. $\mathrm{F}=$ Fatigue (duduk, istirahat, mengusap keringat, meregangkan otot).

d. NA = Not Available (menerima telepon, dipanggil atasan, meninggalkan tempat kerja).

e. 1, 2, 3 dan 4 menunjukkan elemen kerja untuk pekerjaan yang sedang diamatai.

f. Others = operator melakukan pekerjaan lain selain pekerjaan yang sedang diamati.

g. Total = jumlah keseluruhan dari kegiatan ketiga operator yang diamati.

h. Average Rating didapat dari total Performance Rating tiap elemen kerja dibagi dentan total tiaptiap elemen kerja.

i. $\quad$ Output $=$ total hasil keluaran yang dihasilkan oleh operator dari pekerjaan yang diamati selama pengamatan berlangsung.

Perhitungan uji kecukupan data dari jumlah data pengamatan yang telah dilakukan adalah sebagai berikut:

$$
\begin{aligned}
& N^{\prime}=\frac{k^{2}(1-p)}{S^{2} p} \\
& N^{\prime}=\frac{2^{2}(1-0,1767)}{(0,06)^{2}(0,1767)}=5177 \text { data }
\end{aligned}
$$

Dari perhitungan tersebut didapatkan dari persen working $(p)$ terkecil dan dengan tingkat kepercayaan $95 \%$ sehingga nilai $k=2$, dengan mengambil 100 kali pengamatan acak sehingga diperoleh 5177 data dengan tingkat ketelitian 6\% karena $N$ ' belum mencukupi $(\geq 7000)$ dengan 
ketelitian sebesar 5\%. Sehingga perencanaan pengamatan work sampling delakukan selama 3 hari dengan pengamatan acak yang diambil sebanyak 575 kali per hari.

\section{Pengumpulan data work sampling Pengamatan Pertama \\ 1. Pekerja Pertama}

Tabel 2. Pengamatan Pertama Work Sampling Untuk Pekerja Pertama Pada Hari Pertama

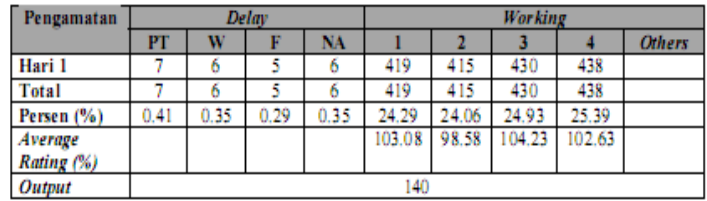

*Hasil Uji Kecukupan Data $=3507$ data

Dari hasil Uji Kecukupan Data tersebut perlu dilakukan pengamatan lagi hingga data yang diambil mencukupi $N^{l} \leq N$, sehingga perlu dilakukan pengamatan selanjutnya dan hasil pengamatan untuk hari kedua dapat dilihat pada Tabel 3 berikut:

Tabel 3. Pengamatan Pertama Work Sampling Untuk Pekerja Pertama Pada Hari Kedua

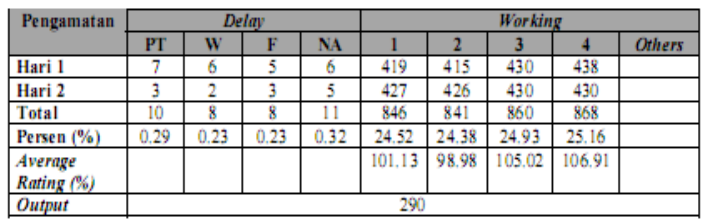

*Hasil Uji Kecukupan Data = 3447 data

Dari hasil Uji Kecukupan Data pada hari kedua diperoleh nilai $N$ ' sebesar 3447 yang nilainya lebih kecil dari nilai $N$ sebesar 3452. Sehingga pengamatan tidak perlu dilakukan lagi karena data telah mencukupi.

\section{Pekerja Kedua}

Tabel 4. Pengamatan Pertama Work Sampling Untuk Pekerja Kedua Pada Hari Pertama

\begin{tabular}{|c|c|c|c|c|c|c|c|c|c|}
\hline \multirow[t]{2}{*}{ Pengamatan } & \multicolumn{4}{|c|}{ Delay } & \multicolumn{5}{|c|}{ Working } \\
\hline & PT & $w$ & $\mathrm{~F}$ & $\mathrm{NA}$ & 1 & 2 & 3 & 4 & Others \\
\hline Hari 1 & 7 & 6 & 5 & 6 & 419 & 415 & 430 & 438 & \\
\hline Total & 7 & 6 & 5 & 6 & 419 & 415 & 430 & 438 & \\
\hline Persen $(\%)$ & 0.41 & 0.35 & 0.29 & 0.35 & 24.29 & 24,06 & 24.93 & 25.39 & \\
\hline $\begin{array}{l}\text { Average } \\
\text { Ruting (\%) }\end{array}$ & & & & & 103.08 & 98.58 & 104.23 & 102.63 & \\
\hline \begin{tabular}{|l|} 
Output \\
\end{tabular} & & & & & 140 & & & & \\
\hline
\end{tabular}

*Hasil Uji Kecukupan Data = 3587 data

Dari hasil Uji Kecukupan Data tersebut perlu dilakukan pengamatan lagi hingga data yang diambil mencukupi $N^{\prime} \leq N$, sehingga perlu dilakukan pengamatan selanjutnya dan hasil pengamatan untuk hari kedua dapat dilihat pada Tabel 5.

Dari hasil Uji Kecukupan Data pada hari kedua diperoleh nilai $N$ ' sebesar 3441 yang nilainya lebih kecil dari nilai $N$ sebesar 3452. Sehingga pengamatan tidak perlu dilakukan lagi karena data telah mencukupi

J@TI Undip, Vol IX, No 3, September 2014
Tabel 5. Pengamatan Pertama Work Sampling Untuk Pekerja Kedua Pada Hari Kedua

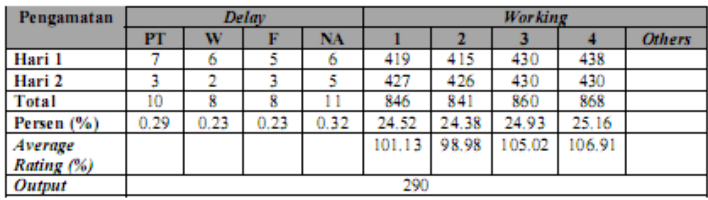

*Hasil Uji Kecukupan Data = 3441 data

\section{Pekerja Ketiga}

Tabel 6. Pengamatan Pertama Work Sampling Untuk Pekerja Ketiga Pada Hari Pertama

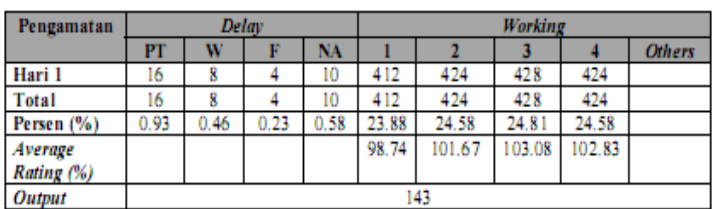

*Hasil Uji Kecukupan Data = 3542 data

Dari hasil Uji Kecukupan Data tersebut perlu dilakukan pengamatan lagi hingga data yang diambil mencukupi $N^{\prime} \leqslant N$, sehingga perlu dilakukan pengamatan selanjutnya dan hasil pengamatan untuk hari kedua dapat dilihat pada Tabel 7 berikut:

Tabel 7. Pengamatan Pertama Work Sampling Untuk Pekerja Ketiga Pada Hari Kedua

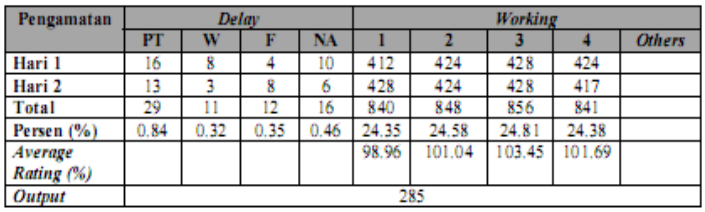

*Hasil Uji Kecukupan Data $=3452$ data

Dari hasil Uji Kecukupan Data pada hari kedua diperoleh nilai $N$ ' sebesar 3452 yang nilainya sama dengan nilai $N$ sebesar 3452. Sehingga pengamatan tidak perlu dilakukan lagi karena data telah mencukupi.

\section{Pengamatan Kedua}

1. Pekerja Pertama

Tabel 8. Pengamatan Kedua Work Sampling Untuk Pekerja Pertama Pada Hari Pertama

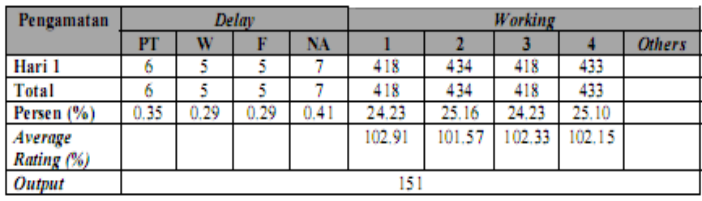

*Hasil Uji Kecukupan Data = 3475 data

Dari hasil Uji Kecukupan Data tersebut perlu dilakukan pengamatan lagi hingga data yang diambil mencukupi $N^{\prime} \leq N$, sehingga perlu dilakukan pengamatan selanjutnya dan hasil pengamatan untuk hari kedua dapat dilihat pada Tabel 9 berikut: 
Tabel 9. Pengamatan Kedua Work Sampling Untuk Pekerja Pertama Pada Hari Kedua

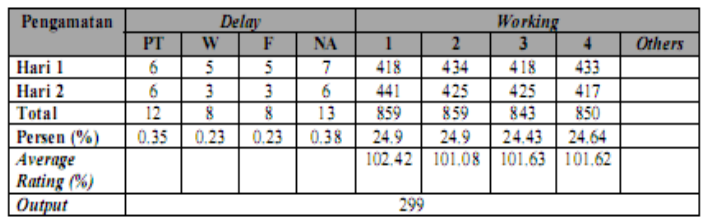

*Hasil Uji Kecukupan Data = 3437 data

Dari hasil Uji Kecukupan Data pada hari kedua diperoleh nilai $N$ ' sebesar 3437 yang nilainya lebih kecil dari nilai $N$ sebesar 3452. Sehingga pengamatan tidak perlu dilakukan lagi karena data telah mencukupi.

\section{Pekerja Kedua}

Tabel 10. Pengamatan Kedua Work Sampling Untuk Pekerja Kedua Pada Hari Pertama

\begin{tabular}{|c|c|c|c|c|c|c|c|c|c|}
\hline \multirow[t]{2}{*}{ Pengamatan } & \multicolumn{4}{|c|}{ Delay } & \multicolumn{5}{|c|}{ Working } \\
\hline & PT & W & $\mathrm{F}$ & $\mathrm{NA}$ & 1 & 2 & 3 & 4 & Others \\
\hline Hari I & 8 & 7 & 3 & 6 & 438 & 436 & 411 & 417 & \\
\hline Total & 8 & 7 & 3 & 6 & 438 & 436 & 411 & 417 & \\
\hline Persen (\%) & 0.46 & 0.41 & 0.17 & 0.35 & 25.39 & 25.26 & 23.83 & 24,17 & \\
\hline $\begin{array}{l}\text { Average } \\
\text { Rating (\%) }\end{array}$ & & & & & 100.3 & 100.25 & 100.61 & 100.34 & \\
\hline Output & & & & & & & & & \\
\hline
\end{tabular}

*Hasil Uji Kecukupan Data = 3552 data

Dari hasil Uji Kecukupan Data tersebut perlu dilakukan pengamatan lagi hingga data yang diambil mencukupi $N^{\prime} \leq N$, sehingga perlu dilakukan pengamatan selanjutnya dan hasil pengamatan untuk hari kedua dapat dilihat pada Tabel 11. berikut:

Tabel 11. Pengamatan Kedua Work Sampling Untuk Pekerja Kedua Pada Hari Kedua

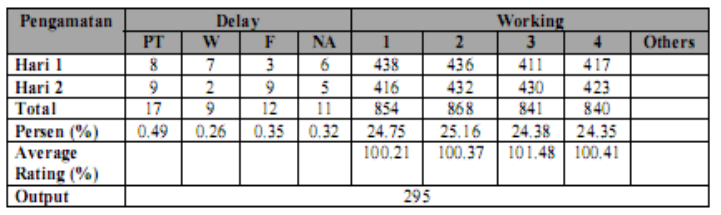

*Hasil Uji Kecukupan Data = 3452 data

Dari hasil Uji Kecukupan Data pada hari kedua diperoleh nilai $N$ ' sebesar 3452 yang nilainya sama dengan nilai $N$ sebesar 3452. Sehingga pengamatan tidak perlu dilakukan lagi karena data telah mencukupi.

\section{Pekerja Ketiga}

Tabel 12. Pengamatan Kedua Work Sampling Untuk Pekerja Ketiga Pada Hari Pertama

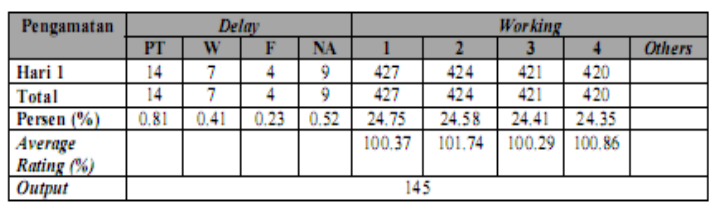

*Hasil Uji Kecukupan Data = 3452 data

Dari hasil Uji Kecukupan Data tersebut perlu dilakukan pengamatan lagi hingga data yang diambil mencukupi $N^{\prime} \leq N$, sehingga perlu dilakukan pengamatan selanjutnya dan hasil pengamatan untuk hari kedua dapat dilihat pada Tabel 13. berikut:

Tabel 13. Pengamatan Kedua Work Sampling Untuk Pekerja Ketiga Pada Hari Kedua

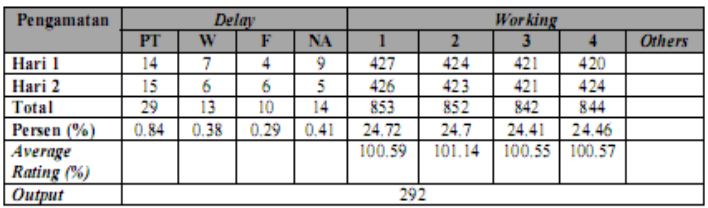

*Hasil Uji Kecukupan Data = 3441 data

Dari hasil Uji Kecukupan Data pada hari kedua diperoleh nilai $N$ ' sebesar 3441 yang nilainya lebih kecil dari $N$ sebesar 3452. Sehingga pengamatan tidak perlu dilakukan lagi karena data telah mencukupi.

\section{Pengamatan Ketiga}

1. Pekerja Pertama

Tabel 14. Pengamatan Ketiga Work Sampling Untuk Pekerja Pertama Pada Hari Pertama

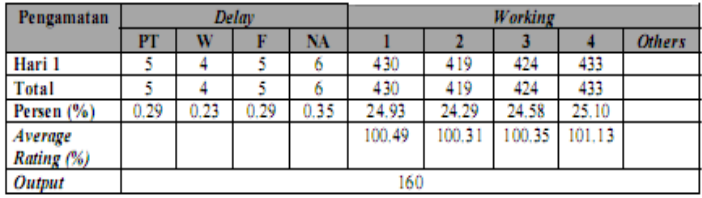

*Hasil Uji Kecukupan Data = 3463 data

Dari hasil Uji Kecukupan Data tersebut perlu dilakukan pengamatan lagi hingga data yang diambil mencukupi $N^{\prime} \leq N$, sehingga perlu dilakukan pengamatan selanjutnya dan hasil pengamatan untuk hari kedua dapat dilihat pada Tabel 15 berikut:

Tabel 15. Pengamatan Ketiga Work Sampling Untuk Pekerja Pertama Pada Hari Kedua

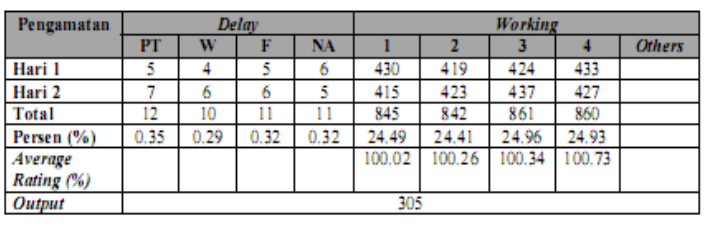

*Hasil Uji Kecukupan Data = 3441 data

Dari hasil Uji Kecukupan Data pada hari kedua diperoleh nilai $N^{\prime}$ sebesar 3441 yang nilainya lebih kecil dari nilai $N$ sebesar 3452. Sehingga pengamatan tidak perlu dilakukan lagi karena data telah mencukupi. 


\section{Pekerja Kedua}

Tabel 16. Pengamatan Ketiga Work Sampling Untuk Pekerja Kedua Pada Hari Pertama

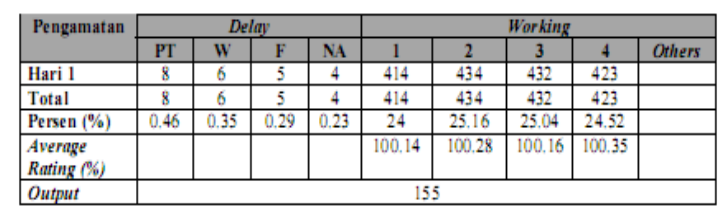

*Hasil Uji Kecukupan Data $=3519$ data

Dari hasil Uji Kecukupan Data tersebut perlu dilakukan pengamatan lagi hingga data yang diambil mencukupi $N^{\prime} \leq N$, sehingga perlu dilakukan pengamatan selanjutnya dan hasil pengamatan untuk hari kedua dapat dilihat pada Tabel 17 berikut:

Tabel 17. Pengamatan Ketiga Work Sampling Untuk Pekerja Kedua Pada Hari Kedua

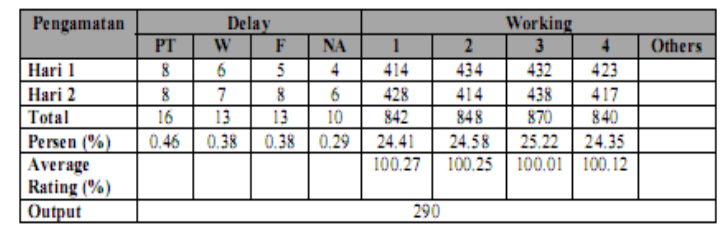

*Hasil Uji Kecukupan Data = 3452 data

Dari hasil Uji Kecukupan Data pada hari kedua diperoleh nilai $N$ ' sebesar 3452 yang nilainya sama dengan nilai $N$ sebesar 3452. Sehingga pengamatan tidak perlu dilakukan lagi karena data telah mencukupi.

\section{Pekerja Ketiga}

Tabel 18. Pengamatan Ketiga Work Sampling Untuk Pekerja Ketiga Pada Hari Pertama

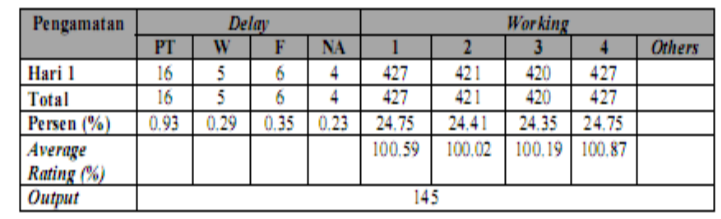

*Hasil Uji Kecukupan Data = 3452 data

Dari hasil Uji Kecukupan Data tersebut perlu dilakukan pengamatan lagi hingga data yang diambil mencukupi $N^{s} \leq N$, sehingga perlu dilakukan pengamatan selanjutnya dan hasil pengamatan untuk hari kedua dapat dilihat pada Tabel 19 berikut:

Tabel 19. Pengamatan Ketiga Work Sampling Untuk Pekerja Ketiga Pada Hari Kedua

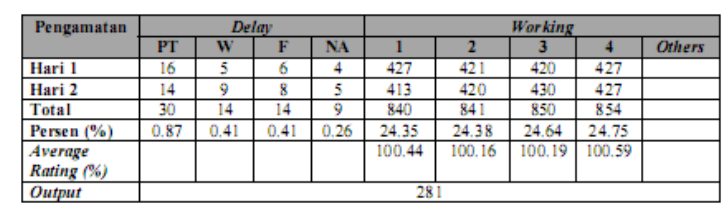

*Hasil Uji Kecukupan Data = 3452 data
Dari hasil Uji Kecukupan Data pada hari kedua diperoleh nilai $N$ ' sebesar 3452 yang nilainya sama dengan nilai $N$ sebesar 3452. Sehingga pengamatan tidak perlu dilakukan lagi karena data telah mencukupi.

\section{Pengolahan Data Work Sampling Pengamatan Pertama}

1. Pekerja Pertama

Tabel 20. Hasil Perhitungan Pengamatan Pertama Work Sampling Untuk Pekerja Pertama

\begin{tabular}{|l|l|}
\hline Uji ketelitian hasil pengamatan & $0.0599 \approx 0.06(6 \%)$ \\
\hline Average\% idle & $1.07 \%$ \\
\hline \% working & $98.99 \%$ \\
\hline \%performance & $103.05 \%$ \\
\hline Total jam pengamatan & $18 \mathrm{jam}$ \\
\hline WN 1 & $0.01539 \mathrm{jam}$ \\
WN 2 & $0.01498 \mathrm{jam}$ \\
WN 3 & $0.01625 \mathrm{jam}$ \\
WN 4 & $0.0167 \mathrm{jam}$ \\
Total WN & $0.06332 \mathrm{jam}$ \\
\hline Waktu standar & $0.0637 \mathrm{jam} / \mathrm{unit}$ \\
\hline Output standar & 15.69 unit/jam \\
\hline
\end{tabular}

\section{Pekerja Kedua}

Tabel 21. Hasil Perhitungan Pengamatan Pertama Work Sampling Untuk Pekerja Kedua

\begin{tabular}{|l|l|}
\hline Uji ketelitian hasil pengamatan & $0.0598 \approx 0.06(6 \%)$ \\
\hline Average \% idle & $1.45 \%$ \\
\hline \% working & $98.35 \%$ \\
\hline$\%$ performance & $102.54 \%$ \\
\hline Total jam pengamatan & 18 jam \\
\hline WN 1 & $0.01588 \mathrm{jam}$ \\
WN 2 & $0.01567 \mathrm{jam}$ \\
WN 3 & $0.01604 \mathrm{jam}$ \\
WN 4 & $0.01566 \mathrm{jam}$ \\
Total WN & $0.06325 \mathrm{jam}$ \\
\hline Waktu standar & $0.06393 \mathrm{jam} / \mathrm{unit}$ \\
\hline Output standar & $15.64 \mathrm{unit} / \mathrm{jam}$ \\
\hline
\end{tabular}

3. Pekerja Ketiga

Tabel 22. Hasil Perhitungan Pengamatan Pertama Work Sampling Untuk Pekerja Ketiga

\begin{tabular}{|l|l|}
\hline Uji ketelitian hasil pengamatan & $0.0599 \approx 0.06(6 \%)$ \\
\hline Average \% idle & $1.97 \%$ \\
\hline$\%$ warking & $98.12 \%$ \\
\hline \% perfarmance & $101.29 \%$ \\
\hline Total jam pengamatan & 18. jam \\
\hline WN 1 & $0.01522 \mathrm{jam}$ \\
WN 2 & $0.01569 \mathrm{jam}$ \\
WN 3 & $0.01621 \mathrm{jam}$ \\
WN 4 & $0.01566 \mathrm{jam}$ \\
Total WN & $0.06278 \mathrm{jam}$ \\
\hline Waktu standar & $0.06404 \mathrm{jam} / \mathrm{unit}$ \\
\hline Output standar & $15.62 \mathrm{unit} / \mathrm{jam}$ \\
\hline
\end{tabular}

\section{Pengamatan Kedua}

1. Pekerja Pertama

Tabel 23. Hasil Perhitungan Pengamatan Kedua Work Sampling Untuk Pekerja Pertama

\begin{tabular}{|l|l|}
\hline Uji ketelitian hasil pengamatan & $0.0599 \approx 0.06(6 \%)$ \\
\hline Average \% idle & $1.19 \%$ \\
\hline$\%$ warking & $98.87 \%$ \\
\hline$\%$ perfarmance & $101.69 \%$ \\
\hline Total jam pengamatan & $18 . \mathrm{jam}$ \\
\hline WN 1 & $0.01535 \mathrm{jam}$ \\
WN 2 & $0.01515 \mathrm{jam}$ \\
WN 3 & $0.01495 \mathrm{jam}$ \\
WN 4 & $0.01507 \mathrm{jam}$ \\
Total WN & $0.06052 \mathrm{jam}$ \\
\hline Waktu standar & $0.06101 \mathrm{jam} / \mathrm{unit}$ \\
\hline Output standar & $16.39 \mathrm{unit} / \mathrm{jam}$ \\
\hline
\end{tabular}


2. Pekerja Kedua

Tabel 24. Hasil Perhitungan Pengamatan Kedua Work Sampling Untuk Pekerja Kedua

\begin{tabular}{|l|l|}
\hline Uji ketelitian hasil pengamatan & $0.06[6 \% 6]$ \\
\hline Average \%6 idle & 1.4296 \\
\hline \% working & 95.6496 \\
\hline \%performance & $100.61 \%$ \\
\hline Total jam pengamatan & $18.3 \mathrm{jam}$ \\
\hline WN 1 & $0.01513 \mathrm{jam}$ \\
WN 2 & $0.015411 \mathrm{jam}$ \\
WN 3 & $0.01510 \mathrm{jam}$ \\
WN 4 & $0.01492 \mathrm{jam}$ \\
Total WN & $0.06056 \mathrm{jam}$ \\
\hline Waktu standar & $0.06123 \mathrm{jam} / \mathrm{unnit}$ \\
\hline Output standar & $16.33 \mathrm{unit} / \mathrm{jam}$ \\
\hline
\end{tabular}

3. Pekerja Ketiga

Tabel 25. Hasil Perhitungan Pengamatan Kedua Work Sampling Untuk Pekerja Ketiga

\begin{tabular}{|l|l|}
\hline Uji ketelitian hasil pengamatan & $0.0599 \approx 0.06(6 \%)$ \\
\hline Average \% idle & $1.92 \%$ \\
\hline \% warking & $98.29 \%$ \\
\hline \% performance & $100.71 \%$ \\
\hline Total jam pengamatan & 18 jam \\
\hline WN 1 & $0.01533 \mathrm{jam}$ \\
WN 2 & $0.01540 \mathrm{jam}$ \\
WN 3 & $0.01513 \mathrm{jam}$ \\
WN 4 & $0.01516 \mathrm{jam}$ \\
Total WN & $0.06102 \mathrm{jam}$ \\
\hline Waktu standar & $0.06196 \mathrm{jam} / \mathrm{unit}$ \\
\hline Output standar & 16.14 unit/jam \\
\hline
\end{tabular}

1. Pengamatan Ketiga

a. Pekerja Pertama

Tabel 26. Hasil Perhitungan Pengamatan Ketiga Work Sampling Untuk Pekerja Pertama

\begin{tabular}{|l|l|}
\hline Uji ketelitian hasil pengamatan & $0.0599 \approx 0.06(6 \%)$ \\
\hline Average \% idle & $1.28 \%$ \\
\hline$\%$ warking & $98.79 \%$ \\
\hline$\%$ perfarmance & $100.34 \%$ \\
\hline Total jam pengamatan & $18 \mathrm{jam}$ \\
\hline WN 1 & $0.01446 \mathrm{jam}$ \\
WN 2 & $0.01444 \mathrm{jam}$ \\
WN 3 & $0.01478 \mathrm{jam}$ \\
WN 4 & $0.01482 \mathrm{jam}$ \\
Total WN & $0.0585 \mathrm{jam}$ \\
\hline Waktu standar & $0.05907 \mathrm{jam} / \mathrm{unit}$ \\
\hline Output standar & $16.93 \mathrm{unit} / \mathrm{jam}$ \\
\hline
\end{tabular}

b. Pekerja Kedua

Tabel 27. Hasil Perhitungan Pengamatan Ketiga Work Sampling Untuk Pekerja Kedua

\begin{tabular}{|l|l|}
\hline Uji ketelitian hasil pengamatan & $0.06(6 \%)$ \\
\hline Average \% idle & $1.51 \%$ \\
\hline$\%$ warking & $98.56 \%$ \\
\hline$\%$ perfarmance & $100.16 \%$ \\
\hline Total jam pengamatan & 18 jam \\
\hline WN 1 & $0.01519 \mathrm{jam}$ \\
WN 2 & $0.01529 \mathrm{jam}$ \\
WN 3 & $0.01566 \mathrm{jam}$ \\
WN 4 & $0.01513 \mathrm{jam}$ \\
Total WN & $0.06127 \mathrm{jam}$ \\
\hline Waktu standar & $0.06203 \mathrm{jam} /$ unit \\
\hline Output standar & $16.12 \mathrm{unit} /$ jam \\
\hline
\end{tabular}

c. Pekerja Ketiga

Tabel 28. Hasil Perhitungan Pengamatan Ketiga Work Sampling Untuk Pekerja Ketiga

\begin{tabular}{|l|l|}
\hline Uji ketelitian hasil pengamatan & $0.06(6 \%)$ \\
\hline Average \% idle & $2.05 \%$ \\
\hline$\%$ warking & $98.12 \%$ \\
\hline \% perfarmance & $100.35 \%$ \\
\hline Total jam pengamatan & $18 \mathrm{jam}$ \\
\hline WN 1 & $0.01567 \mathrm{jam}$ \\
WN 2 & $0.01564 \mathrm{jam}$ \\
WN 3 & $0.01581 \mathrm{jam}$ \\
WN 4 & $0.01595 \mathrm{jam}$ \\
Total WN & $0.06307 \mathrm{jam}$ \\
\hline Waktu standar & $0.06415 \mathrm{jam} / \mathrm{unit}$ \\
\hline Output standar & $15.59 \mathrm{unit} / \mathrm{jam}$ \\
\hline
\end{tabular}

J@TI Undip, Vol IX, No 3, September 2014
Pengolahan Uji Pengaruh dengan Menggunakan One-Way ANOVA

Berdasarkan hasil pengujian One-Way ANOVA didapatkan bahwa nilai P sebesar 0.001 yang nilainya kurang dari nilai $\alpha$ yaitu sebesar 0.05 , sehingga dari nilai $\mathrm{P}$ tersebut dapat disimpulkan bahwa terdapat pengaruh pada penggunaan APD terhadap Allowance.

Berdasarkan Tabel 29 dapat terlihat bahwa allowance yang sering dilakukan oleh pekerja adalah Personal Time $(P T)$ baik pada Pekerja pertama, kedua dan ketiga. Sedangan Waiting $(W)$ dan Fatigue $(F)$ lebih sering terjadi pada pekerja ketiga yang hanya mengenakan APD berupa cattle pack dan sepatu safety.

Tabel 29. Perbandingan Nilai Allowance

\begin{tabular}{lccc}
\multicolumn{1}{c}{ Kategori } & PT & W & F \\
\hline Pekerja Pertama & 34 kali & 26 kali & 27 kali \\
Pekerja Kedua & 51 kali & 31 kali & 35 kali \\
Pekerja Ketiga & 88 kali & 38 kali & 36 kali \\
\hline
\end{tabular}

\section{Kesimpulan}

Berdasarkan hasil penelitian yang telah dilakukan didapatkan waktu normal rata-rata sebesar 0.06078 jam untuk pekerja pertama (memakai APDsepatu safety, cattle pack, masker, kacamata dan helmet), 0.06169 jam pekerja Kedua (memakai APD sepatu safety, cattle pack dan kacamata) dan 0.06229 jam untuk pekerja Ketiga (memakai sepatu safety dan cattle pack). Sedangkan waktu standarnya didapatkan nilai rata-rata sebesar 0.06126 jam/unit untuk pekerja Pertama, 0.0624 jam/unit untuk pekerja Kedua dan 0.06338 jam/unit untuk pekerja Ketiga. Dan waktu normal dan waktu standar yang paling baik nilainya adalah yang dihasilkan oleh pekerja Pertama.

Dari hasil pengujian dengan one-way ANOVA didapatkan bahwa nilai P sebesar 0.001 yang nilainya kurang dari nilai $\alpha$ yaitu sebesar 0.05 , sehingga dari nilai $\mathrm{P}$ tersebut dapat disimpulkan bahwa terdapat pengaruh pada penggunaan APD terhadap Allowance.

Pada output standart rata-rata yang dihasilkan pada pekerjaan kayu didapatkan 16.34 unit/jam untuk pekerja Pertama, 16.03jam/unit untuk pekerja Kedua dan 15.78 jam/unit untuk pekerja Ketiga. Mka output terbesar dihasilkan ole pekerja Pertama.

\section{Daftar Pustaka}

Occupational Safety and Health Administration (OSHA).

Undang-Undang Keselamatan dan Kesehatan Kerja (2009).UU. No. 1 Tahun 1970 tentang Keselamatan Kerja,

Kavianian, H. R. dan C. A. Wentz, Jr (1990). Occupational and Environtment Safety Engineering and Management. Van Nostrad Reinhold, New York.

Wignjosoebroto, Sritomo (2003). Ergonomi Studi Gerak dan Waktu: Teknik Analisa Untuk Peningkatan Produktivitas Kerja. Guna Widya, Surabaya. 